\title{
The Use of Serological Tests (I.F.A.T. and iELISA) for Evaluation of Specific Antibodies Level in Vaccinated and Nonvaccinated Animals Against Anthrax
}

\author{
Prof. As. Etleva Hamzaraj \\ University of Tirana, Faculty of Natural Sciences, Department of Biology
}

Msc. Besa Ndoci

Food Safety and Veterinary Institute, Department of Animals Helth

\author{
Prof. Dr. Pëllumb Muhedini
}

Food Safety and Veterinary Institute, Department of Vaccine Production

Msc. Agim Kruja

Food Safety and Veterinary Institute, Department of Vaccine Production

\section{Doi:10.5901/ajis.2013.v2n9p642}

\section{Abstract}

\begin{abstract}
Various diseases, especially infectious ones, have caused untold harm to humanity in centuries. Among these, special attention should be paid to infectious diseases, especially anthrax, which reduces a lot the number of heads and livestock products. One of the most important tools to combat this infection are vaccinations. Today there are different kinds of vaccines against anthrax. The aim of this study was the use of IFA tests and IELISA to determine the efficacy of vaccines against anthrax. For the implementation of the IFA test bacterial emulsions prepared with bacterial strains of B. anthracis Stern 34F2 and Pasteur were used as antigens. As for determining the level of antibodies in the serum by iELISA was used Anthrax Protective antigen IgG ELISA kit. Sera of sheep and goat vaccinated with capsular and noncapsular vaccines were analyzed with both methods 21 days, 9 months and 12 months after vaccination. The results obtained show that sheep respond better to the vaccine than goat. The index of IgG anti-PA antibodies between vaccines, determined by ELISA, varies from 3.3 to 1.6 and 3.85 to 1.94, respectively, in the sera of animals vaccinated with noncapsular and capsular vaccines 21 days and 12 months after vaccination. For evaluation of vaccine immunogenicity, techniques of $\lg G$ anti-PA ELISA and indirect immunofluorescence (IFAT) can be used as alternative methods of control by the State Laboratory of Control of Veterinary Bioproducts.
\end{abstract}

\section{Introduction}

Various diseases, especially infectious ones, have caused for centuries untold harm to humanity. Among these diseases has been the anthrax. As a antropozoonotic disease, it was one of the haviest in the past, causing damage to people and animals. Socio-economic conditions before Second World War on one hand, the lack of specialists and the low level of veterinary service on the other, have been the most important factors that have kept in high levels the morbidity and mortality of many infectious diseases, as well as anthrax.

Currently, the increased number of livestok and consequently of their products require increased care to protect the animals from various diseases. Among these, special attention should be paid to infectious diseases, especially anthrax, which reduces a lot the number of heads and livestock products. Therefore, combating and prevention of this infection is a significant problem.

One of the most important tools to combat this infection are profilactic vaccinations, which play a major role in limiting the disease and prevent damage (Turnbull, 1991). Today there are different kinds of vaccines against anthrax, from those with various stimulants, with capsular and noncapsular strains, to vaccines prepared with synthetic media socalled Protective Antigen, isolated from the toxic complex of anthrax bacillus.

Noncapsular vaccines are widely used in veterinary practice because of some features of strains, such as:

1. lack of capsule, which allows the phagocytosis of bacteria and promotes the creation of a humoral and cellular immunity in a large scale; 
2. are nonvirulent for guinea pigs;

3. are stable and do not have the manufacturing capability of the capsule as in vivo and in vitro;

4. maintain good antigenic skills;

5. they are safe and can be used in all kinds of animals;

6. the immunity driven by them is stable for at least 1 year;

7. do not contaminate the surrounding environment, having a significant impact on animal health and veterinary public health.

These vaccine noncapsular strains after entry into the animal body, multiply and develop toxic complex. In response, the animal body develops specific antibodies representing complex factors of cellular and humoral defense, neutralizing the toxic complex of virulent strains of anthrax bacillus. Therefore, today the immunity to anthrax is considered as antitoxic and antiinfectiv, while antibodies are identified as antitoxin (Beyer, 1996, Gajic, 1980, Klein, 1962., OIE 2000).

Based on this concept, to evaluate the effectiveness of vaccines against anthrax disease, in addition to biological tests on laboratory or homologous animals, are used also different serological tests such as seroneutralisation, indirect imunofluorescence, ELISA, etc. (Carcani , 1976, Jawets, 1982, Muhedini, 1990).

According to our researchers (Xinxo, Muhedini, 1998), anthrax disease in cattle has been widespread throughout the country, especially in the period before second world war. The annual mass vaccination and (in many affected areas also 2-3 times a year), as well as other antiepizootic versatile measures led to a noticeable reduction of anthrax disease.

Based on many years of statistics, most cases of anthrax were reported for sheep, goats, cattle, horses and pigs. Vaccination of cattle, as a prophylactic measure, to which was given priority after 1950, led to a noticeable and incomparable reduction of anthrax disease, a situation which led also to a reduction of the incidence of this disease in humans (Muhedini, 2007).

Anthrax exists virtually in all countries of the world, but especially in Asia, Latin America, Africa and some European countries. The existence of the disease depends on seasonal fluctuations, with the highest incidence in summer, especially during warm and dried seasons (OIE 2000, Turnbull, 1993).

\section{Materials and Methods}

One of the objectives of our study was to evaluate the level of specific antibodies against the anthrax bacillus in the serum of animals vaccinated with noncapsular and capsular vaccines compared to nonvaccinated animals using the IFA test. For the realisation of this task we used two strains: $B$. anthracis Stern " $34 F_{2}$ " noncapsular and B. anthracis "Pasteur" capsular with mesogen virulence. These strains were used for preparation of antigen solution for indirect imunofluorecsence test.

At the beginning, lyophilized strains were cultivated and analyzed for their characteristics. Afterwards they were cultivated in bottles with TSB media where, once microbial concentration was determined and microbial cultures resulted macro- and microscopically clean, wered inactivatded with $0.5 \%$ formalin and stored at $+4^{\circ}$ up to $+6^{\circ} \mathrm{C}$.

For determination of antibody titers in the sera of vaccinated and control animals we used the available sera in the production of bio-products sector, the Institute of Food Safety and Veterinary (VRI) - Tirana. The sera used were obtained from sheep and goat vaccinated with capsular and noncapsular vaccine 21 days, 9 and 12 months after vaccination, and from control sheep and goat (the unvaccinated), which were lyophilised and stored at $-40^{\circ} \mathrm{C}$.

To perform the assembly of antigen-antibody reaction for every type of antigen we used one slide with 15 wells. In every well of the first slide was added $5 \mu \mathrm{l}$ antigen of the noncapsular strain of bacillus anthracis. Slides were left at room temperature for drying. For antigen fixation we used acetone at $-20^{\circ} \mathrm{C}$. The same procedure was followed also for the capsular antigen of anthrax bacillus. After fixing antigens in the wells of the first line were addes $5 \mu$ sera from vaccinated goats with noncapsular vaccine, in the second line was laid subtitled $5 \mu \mathrm{l}$ sera from vaccinated goats with capsular vaccine, while in the third line $5 \mu \mathrm{l}$ sera from nonvaccinated goats. The same protocol was followed also for the capsular antigen

In every well were antigen-antibody imunocomplex was mounted, we added $5 \mu$ conjugate, respectively according to species, which were covered with aluminium foil and were incubated for 30 minutes at $37^{\circ} \mathrm{C}$. The fluorescein conjugate (Nordic) was prepared with rabbit sera anti sheep and goat IgG. The assessment of prepared slides was done in fluorescence microscope in due time. Evaluation criteria of slides examined in fluorescence microscope were based primarily on examination of the microbial cell shape and of specific brightness (halo). Based on fluorescence intensity, assessment of slides was made using $(+)$. In consideration for positivity were those slides assessed with 2,3 and $4(+)$ (Feteanu A., 1967). 
The second objective of our study was evaluation of the level of specific antibody against the anthrax bacillus in serum of animals vaccinated with capsular and noncapsular vaccines, compared with the level of antibodies in nonvaccinated animals. Anthrax Protective antigen IgG ELISA is a imunoenzyme assay (EIA), which is used for detection of antitoxic antibodies to $B$. anthracis protective antigen in vaccinated animals or in those exposed to $B$. anthracis. Microtitration plate wells are coated with $B$. anthracis protective antigen. If IgG specific antibodies to $B$. anthracis protective antigen are present in a serum sample, they will be linked to antigen that lines the wells of microtitration plate.

The diagnosis is determined by comparing the OD of the samples tested, the OD of positive control. Sera used were obtained from sheep vaccinated with capsular and noncapsular vaccines 21 days, 9 months and 12 months after vaccination and from control sheep (unvaccinated), which were lyophilized and stored at $-40^{\circ} \mathrm{C}$. Results are read by means of a photometer (ELISA reader) at $450 \mathrm{~nm}$ wavelength.

\section{Results and discussion}

As mentioned above one of the goals of our research was to study the level of specific antibodies against the anthrax bacillus in the serum of animals vaccinated with capsular and noncapsular vaccines compared to antibody levels in the serum of nonvaccinated animals using IFA test. We used two lyophilised strains as antigens to determine the level of specific antibodies against the anthrax bacillus through indirect imunofluorescence. For this purpose initially we defined cellular, cultural and biochemical characteristics of both strains, so that we were sure of the purity of cultures.

After 18-24 hours of incubation in $37^{\circ} \mathrm{C}$, in aerobic conditions, noncapsular vaccine strain "Stern $34 \mathrm{~F} 2$ " and the capsular one "Pasteur" of the anthrax bacilli grew in very characteristic colonies, from 0.5 to $4 \mathrm{~mm}$ in diameter and with white to light gray color. When cultivated in 5-10\% blood agar, two strain formed round colonies, from 0.5 to $6 \mathrm{~mm}$ in dimeter and with all the features observed in plain agar media. Noncapsular vaccine strain colonies on blood agar manifested an almost insignificant hemolysis that was never bigger than the colony itself, while colonies of capsular vaccine strain had almost the same size, but did not manifest hemolysis. In microscopic slides prepared after 18-24 hours of incubation at $37^{\circ} \mathrm{C}$ cells appear in the form of long strings and resulted Gram positive after Gram stain

Strains of $B$. anthracis are static. To test this feature two strains were cultivated with injection in semi-solid agar media. After $18-24$ hours of incubation at $37^{\circ} \mathrm{C}$ was found that cultures were grown only at the injection site and the rest of media was clear. The study of fermentation and biochemical characteristics, vaccine strains of anthrax bacillus was conducted in different media with sugars and other differentiate media, prepared according to known protocols (Antonova V., Blinov PN 1971 Burans J 1996, Buxton A. 1977). Once we were sure of the purity of our cultures, we prepared bacterial solutions with certain concentrations that we used later for the IFA test. The concentration of microbial strains of anthrax bacteria was determined by standard optical McFerland.

Table 1: The level of specific antibodies against the anthrax bacilli in the serum of vaccinated goats with noncapsular and capsular vaccines, compared with the level of serum antibodies in vaccinated goats with the IFA test, 21 days after vaccination

\begin{tabular}{|c|c|c|c|c|c|c|c|c|c|}
\hline \multirow{2}{*}{ No. } & \multirow{2}{*}{ Goat Serum } & \multirow{2}{*}{ Antigen } & \multicolumn{9}{|c|}{ Serum dilutions } \\
\cline { 5 - 10 } & & & $1 / 2$ & $1 / 4$ & $1 / 8$ & $1 / 16$ & $1 / 32$ & $1 / 64$ & $1 / 128$ \\
\hline 1 & noncapsular & noncapsular & +++ & +++ & +++ & +++ & +++ & ++ & ++ \\
\hline 2 & capsular & " & +++ & +++ & +++ & +++ & +++ & ++ & ++ \\
\hline 3 & control & " & - & - & - & - & - & - & - \\
\hline 1 & noncapsular & Capsular & +++ & +++ & +++ & +++ & +++ & ++ & ++ \\
\hline 2 & capsular & " " & +++ & +++ & +++ & +++ & +++ & ++ & ++ \\
\hline 3 & control & " & - & - & - & - & - & - & - \\
\hline
\end{tabular}

Note: the ordinal numbers 1 and 2 represent the four serums obtained from four animal where the protection power is determined by DFM., while No. 3 represents the serum of four unvaccinated animals. Pozitive titer was considered that with $2(+)$ and above. 

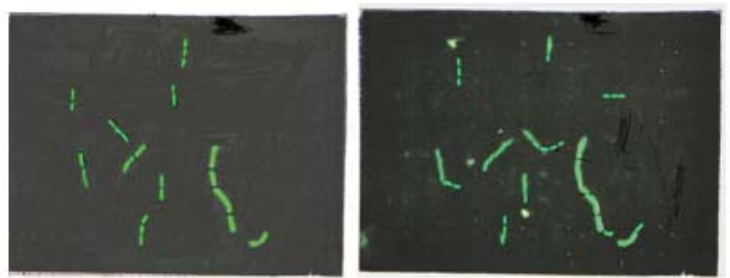

Photo 1: Indirect immunofluorescence with sera of vaccinated goats with noncapsular vaccine, 21 days after vaccination (left, 10). Indirect immunofluorescence with sera of vaccinated goats with capsular vaccine, 21 days after vaccination (right, 11).

Table 2: The level of specific antibodies against the anthrax bacilli in the serum of vaccinated goats with noncapsular and capsular vaccines, compared with the level of serum antibodies in vaccinated goats with the IFA test, 12 months after vaccination.

\begin{tabular}{|c|c|c|c|c|c|c|c|c|}
\hline \multirow{2}{*}{ Goat serum } & \multirow{2}{*}{ Antigen } & \multicolumn{7}{|c|}{ Serum dilutions } \\
\cline { 3 - 9 } & Noncapsular & $1 / 2$ & $1 / 4$ & $1 / 8$ & $1 / 16$ & $1 / 32$ & $1 / 64$ & $1 / 128$ \\
\hline Noncapsular & " & +++ & +++ & +++ & +++ & ++ & + & - \\
\hline Capsular & " & + & +++ & +++ & +++ & ++ & + & - \\
\hline Controle & Capsular & +++ & +++ & +++ & +++ & ++ & + & - \\
\hline Noncapsular & " " & +++ & +++ & +++ & +++ & ++ & + & - \\
\hline Capsular & " " & - & - & - & - & - & - & - \\
\hline Controle & \multicolumn{2}{|c|}{} & & & & & & - \\
\hline
\end{tabular}

Pozitive titer was considered that with $2(+)$ and above.

Table 3. The level of specific antibodies against the anthrax bacilli in the serum of vaccinated sheep with noncapsular and capsular vaccines, compared with the level of serum antibodies in vaccinated goats with the IFA test, 21 days after vaccination

\begin{tabular}{|c|c|c|c|c|c|c|c|c|}
\hline \multirow{2}{*}{ Sheep serum } & \multirow{2}{*}{ Antigen } & \multicolumn{7}{|c|}{ Serum dilutions } \\
\cline { 3 - 9 } & Noncapsular & $1 / 2$ & $1 / 4$ & $1 / 8$ & $1 / 16$ & $1 / 32$ & $1 / 64$ & $1 / 128$ \\
\hline Noncapsular & " & +++ & ++++ & ++++ & ++++ & +++ & +++ & ++ \\
\hline Capsular & " & - & - & - & - & - & - & - \\
\hline Controle & Capsular & ++++ & ++++ & ++++ & ++++ & +++ & +++ & ++ \\
\hline Noncapsular & " " & ++++ & ++++ & ++++ & ++++ & +++ & +++ & ++ \\
\hline Capsular & " & - & - & - & - & - & - & - \\
\hline Controle & & & & & & & & ++++ \\
\hline
\end{tabular}

Pozitive titer was considered that with $2(+)$ and above.

Table 4. The level of specific antibodies against the anthrax bacilli in the serum of vaccinated sheep with noncapsular and capsular vaccines, compared with the level of serum antibodies in vaccinated goats with the IFA test, 9 months after vaccination

\begin{tabular}{|c|c|c|c|c|c|c|c|c|}
\hline \multirow{2}{*}{ Sheep serum } & \multirow{2}{*}{ Antigen } & \multicolumn{9}{|c|}{ Serum dilutions } \\
\cline { 3 - 9 } & & $1 / 2$ & $1 / 4$ & $1 / 8$ & $1 / 16$ & $1 / 32$ & $1 / 64$ & $1 / 128$ \\
\hline Noncapsular & Noncapsular & ++++ & ++++ & ++++ & +++ & +++ & ++ & + \\
\hline Capsular & " & ++++ & ++++ & ++++ & +++ & +++ & ++ & + \\
\hline Controle & " & - & - & - & - & - & - & - \\
\hline Noncapsular & Capsular & ++++ & ++++ & ++++ & +++ & +++ & ++ & + \\
\hline Capsular & " " & ++++ & ++++ & ++++ & +++ & +++ & ++ & + \\
\hline Controle & " " & - & - & - & - & - & - & - \\
\hline
\end{tabular}


Pozitive titer was considered that with $2(+)$ and above.

Table 5. The level of specific antibodies against the anthrax bacilli in the serum of vaccinated sheep with noncapsular and capsular vaccines, compared with the level of serum antibodies in vaccinated goats with the IFA test, 12 months after vaccination

\begin{tabular}{|c|c|c|c|c|c|c|c|c|}
\hline \multirow{2}{*}{ Sheep serum } & \multirow{2}{*}{ Antigen } & \multicolumn{9}{|c|}{ Serum dilutions } \\
\cline { 3 - 9 } & Noncapsular & $1 / 2$ & $1 / 4$ & $1 / 8$ & $1 / 16$ & $1 / 32$ & $1 / 64$ & $1 / 128$ \\
\hline Noncapsular & " & +++ & ++++ & ++++ & +++ & ++ & + & - \\
\hline Capsular & " " & - & - & - & - & - & - & - \\
\hline Controle & Capsular & ++++ & ++++ & ++++ & +++ & ++ & + & - \\
\hline Noncapsular & " " & ++++ & ++++ & ++++ & +++ & ++ & + & - \\
\hline Capsular & " " & - & - & - & - & - & - & - \\
\hline Controle & & & & & & & & + \\
\hline
\end{tabular}

Pozitive titer was considered that with $2(+)$ and above

The data of tables 1 and 2 show that serum titers of vaccinated goats with noncapsular and capsular vaccines against anthrax, using both antigens, gave, respectively, fluorescence with $2(+)$ at dilutions 1/128 (21 days after vaccination) and 1/32 (12 months after vaccination). The data tables 3, 4 and 5 showed that serum titers of vaccinated sheep with noncapsular and capsular vaccines against anthrax, using both antigens, gave, respectively, fluorescence with $2(+)$ at dilutions 1/128, 1/64 and 1/32 after 21 days, 9 and 12 months of vaccination.

In parallel with the sera of vaccinated sheep and goats, it was evaluated also through IFA test the sera of nonvaccinated animals. In all reactions realized the sera of control animals gave no fluorescence even in smaller dilutions such as 1:2 and 1: 4. Applying the technique of indirect imunofluorescence in determining the level of antibody titer is specific and possible to be carried out.

From the data obtained there is a more pronounced fluorescence intensity in the serum of vaccinated sheep than the serum of vaccinated goats, although their serum titer is the same in the same time periods after vaccination. The results obtained show a better response of sheep to the vaccine than goats. These results are supported even better by determination of defensive power and its duration during biological test conducted by the Biopharmaceuticals Manufacturing Sector, VRI (P. Carcani, Jim A.-1976, Muhedini P. 1990.)

During our study we defined the level of specific antibodies against $B$. anthracis in serum of animals vaccinated with capsular and noncapsular vaccines compared with the level of serum antibodies in nonvaccinated animals with the ELISA test. Sera used for the realization of the ELISA test is originated from animals on which it was performed determination of defensive power of the capsular and noncapsular vaccines, which resisted experimental infection with virulent $B$. anthracis strain Laç 478, respectively, 1, 10, 50 and 100 minimal lethal dose after 21 days, 9 and 12 months of vaccination. For determination of protective power of each vaccine in different periods after vaccination we used 4 vaccinated sheep and 1 infected sheep with 1,10 and 100 minimal lethal dose (mld) of virulent strains of $B$. anthracis 478 Laç. We note that sheep vaccinated with noncapsular $B$. anthracis strains were infected 21 days after vaccination with 10 and $50 \mathrm{mld}$ and 9 and 12 months after vaccination were infected with $10 \mathrm{mld}$, while sheep vaccinated with the capsular vaccine were infected with $100 \mathrm{mld}, 21$ days and 9 and 12 months after vaccination.

Based on the results of the test performed in our lab we can present these data:

1. The average index of IgG antibodies anti protective antigen of sheep serum 21 days after vaccination, vaccinated with noncapsular vaccine resulted 3.3

2. The average index of IgG antibodies anti protective antigen of sheep serum 9 months after vaccination, vaccinated with noncapsular vaccine resulted 2

3. The average index of IgG antibodies anti protective antigen of sheep serum 12 months after vaccination resulted vaccinated with noncapsular vaccine resulted 1.6

4. The average index of IgG antibodies anti protective antigen of sheep serum 21 days after vaccination, vaccinated with capsular vaccine resulted 3.85

5. The average index of $\lg G$ antibodies anti protective antigen of sheep serum 9 months after vaccination, vaccinated with capsular vaccine resulted 2.54

6. The average index of IgG antibodies anti protective antigen of sheep serum 12 months after vaccination, vaccinated with capsular vaccine resulted 1.94 
The difference of IgG anti-PA index and its duration, determined with Anthrax Protective antigen IgG ELISA test, between serum from animals vaccinated with the vaccine produced with capsular and noncapsular strain of $B$. anthracis is understandable because the noncapsular vaccine is produced from an almost apatogen strain for laboratory animals and that between them, the $B$. anthracis strains used in vaccine production must necessarily be changes in the antigenic structure, as production of protective antigen is largely determined by pxO1plasmid. While the loss or decline in virulence of $B$. anthracis not only due to the loss of plasmid kapsuloformues, pxO2, but also with changes in plasmid toxicity, this leads to the conclusion that, at the same time there is a shift into a plasmid that determines production of protective antigen and other factors as toxic Lethal factor and Edema factor and consequently the immunity boost by almost avirulent vaccine strains of $B$. anthracis to homologous animals is in lower level compared to the strains of mesogene virulence (Anderson GL, Simchock JM, Ëilson KH. 1996).

The arguments mentioned above are also supported by this paper as $\lg G$ antibody index between anti-PA vaccine varies from 3.3 to 1.6 and 3.85 to 1.94 respectively in sera of animals vaccinated with capsular and noncapsular vaccine 21 day 12 months after vaccination. Based on the determination of the protective power of capsular and noncapsulare vaccines applied in sheep in the Sector of Production of biopharmaceuticals it is proved that the values 1.6 to 1.94 of index of IgG anti-PA antibodies obtained from sera of vaccinated sheep with capsular and noncapsular vaccines protect these animals respectively 10 and 100 mld, 12 months and 9 months after vaccination.

Currently it is accepted that IgG ELISA serological test in microtitration plates coated with protective antigen (PA) compared with all other serological tests is the best and has a sensitivity $97.6 \%$ and specificity from 94.2 to $98 \%$ (Turnbull PCB, 2007.). In addition to high sensitivity and specificity, this test is simpler and requires less time to analyze the serum.

In conclusion we can say that or evaluation of vaccine imunogenicity, techniques of IgG anti-PA ELISA and indirect immunofluorescence (IFAT) can be used as alternative methods of control by the State Laboratory of Control of Veterinary Bioproducts. Serological tests anti-PA IgG ELISA and indirect immunofluorescence (IFAT) tests can be used to monitor the epidemiological situation and to identify vaccinated animals.

\section{References}

Anderson G.L., Simchock J.M., Wilson K.H. (1996) Identification of a region of genetic variability among Bacillus anthracis strains and related species. J Bacteriol, 178, 377-84.

Antonova V., Blinova P.N., (1971) Laboratornos isvedovania veterinarii.

Beyer W, Glöckner P, Otto J, Böhm R., (1996) A nested PCR and DNA-amplifcation-fingerprinting method for detection and identification of Bacillus anthracis in soil samples from former tanneries. Salisbury Med Bull, 87, special suppl:47-9.

Burans J., Keleher A., O'Brien T., et al., (1996) Rapid method for the diagnosis of Bacillus anthracis infection in clinical samples using a hand-held assay. Salisbury Med Bull, 87, special suppl:36-7.

Carcani P., Dashi A., (1976), Studimi i cilësive imunologjike të vaksinës kundër plasjes për standartizimin e prodhimit dhe kontrollit të saj. Buletini i Shkencave Bujqësore, 1.

Feteanu A., (1967), L'identificatin et la differenciation de B. anthracis dans les cultures et les tissus des autres germes du germe bacillus a l'aide des anticorpe fluorescents. Arciva Veterinaria.

Gajiq S., Levi E., Jovanoviq J.M. (1970), Microbiologija e bacteriologija, 408-410.

Jawets E., (1982), Review of medical microbiology, 15 edition, $207-215$.

Klein F., Lincoln R.E., (1962), Immunologic studies of anthrax, J. Immun., 431 - 437.

O.I.E. 2000, Manual of standards for diagnostic tests and vaccines.

Muhedini P., (1990), Studimi për prodhimin e një vaksine kundër plasjes me shtam akapsular "Stern 34 F2" e krahasimi i vlerave të saj me ato të vaksinës ekzistuese për kushtet e vendit tonë, ISUV, Tirane

Muhedini P., (2007), Monitorimi i situatës epidemiologjike i sëmundjeve zoonotike në Shqipëri, ISUV, Tirane

Turnbull P.C.B., (1991), Anthrax vaccines: past, present and future. Vaccine, 9, 533-9.

Turnbull P.C.B., Bohm R., Chizyuka H.G.B., et al., (1993) Guidelines for the Surveillance and Control of Anthrax in Humans and Animals. World Health Organization, Geneva, 170.

Turnbull P.C.B., (2007), Specific, Sensitive, and Quantitative Enzyme-Linked Immunosorbent Assay for Human Immunoglobulin G Antibodies to Anthrax Toxin Protective Antigen, Microbiol Immunol, 177, 293-303.

Xinxo A., Muhedini P., (1998), Plasja, aspekte epidemiologjike private, Revista Mjekësore,2, 16-22. 